\title{
Personal Finance Education: An Early Start To A Secure Future
}

Michele Herman, (E-mail: herman@shsu.edu), Sam Houston State University

Balasundram Maniam, (E-mail: GBA_BXM@shsu.edu), Sam Houston State University

\begin{abstract}
The lack of mandated personal finance curriculum in American schools is an issue that has gained considerable momentum in recent years. Studies have indicated that personal finance education contributes to financial literacy and financial success. Although some strides have been made to incorporate personal finance education into core curriculum, statistics show that American students are financially illiterate. This paper investigates the impact of personal finance education on financial well-being and presents arguments for including personal finance education into core curriculum. This paper also provides an overview of the current trends in the US economy that are dramatically affecting the financial management behaviors of American households and their financial well-being
\end{abstract}

\section{INTRODUCTION}

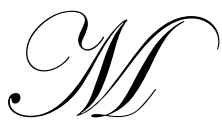

any individuals suffer through life with poor financial management skills because of a lack of education. Many educators, community groups, businesses, government agencies and policymakers are becoming increasingly concerned with financial literacy. Numerous studies, which have tracked and measured levels of financial literacy, have all reached the same conclusion: Financial literacy among consumers is unacceptably low. Considering that many of the financial decisions we make throughout our lives will influence the general well-being of individuals and society as a whole, this low level of financial literacy is understandably a great concern.

Individuals deal with financial management on a daily basis, and whether it is budgeting for groceries, buying clothing, purchasing a home or car, or paying for college, many of the financial decisions we make today can have residual effects that last a lifetime. A bad credit score can lead to a higher mortgage interest rate, which can lead to less purchasing power when buying a home and paying thousands more in interest during the life of the mortgage. The amount of money put aside in college funds will directly impact the choice of which college to attend. Learning to manage money wisely is a challenging task for many, even more so for individuals who lack basic financial skills and who have little to no experience with financial management. Yet, when it comes to personal financial education in the US, many schools are failing to adequately educate students on financial management.

Often education focuses on how to become an income-earning citizen, with little focus on how to wisely manage the income received. Today, much of what individuals learn about personal finance comes from their families. However in many households, parents spend very little time discussing everyday financial matters with their children or including them in budgeting and purchasing decisions. Although many schools teach the fundamentals of economics and math, personal finance education deals with the topics which are not typically covered in the economics and math disciplines, such as budgeting, investing, cash flow and credit management. Until recently many schools in the US did not mandate or even offer personal financial education to students. It is imperceptible to many experts that in a society with sophisticated and incomparable financial markets and in a time where there exists a free flow of information, specifically financial information; there exists a shortfall of personal finance curricula in the US education system. Teaching children and young adults financial skills is essential to their future financial success and will help ensure that they will have the tools to cope with major financial decisions later in life. Providing personal 
finance curricula in schools is crucial because it provides the basic skills that can be built on to as individuals mature into adulthood.

\section{LITERATURE REVIEW}

A 2005 study undertaken by Mandell asked the question of whether financial literacy makes a difference in the lives on consumers. Mandell focuses on the behavior referred to by economists as propensity to save, theorizing that since propensity to save is one of the strongest determinants of financial success or failure, it would be most useful to analyze its relationship to financial literacy. In his study, Mandell points out that to truly measure financial literacy and the effect on propensity to save, one would need to conduct a more in depth study which would track the financial success of a cohort of consumers from early adulthood or conduct a study of two sample of consumers, one group who have experienced financial failure and another group who have experienced financial success. Unfortunately, both studies are time and resource intensive and since financial records are typically confidential and not easily accessible to researchers, there are few aggregate measures of the effects of financial literacy. However, the survey conducted by Mandell is an excellent reference point for future studies on the effects of financial literacy (Mandell, 2005)

The Jumpstart Coalition conducted a survey regarding financial literacy of high school students, which Mandell later studied. The survey is a 31 question, age appropriate, and multiple choice tests and is distributed to a sample of approximately 4,000 high school students every two years. The results of the survey have proven that students are fairly financially illiterate, which has continued in a downward trend since then. Mandell evaluated the survey results to determine the correlation between financial literacy and propensity to save. The results of Mandell's study have found that financial education does contribute, although only slightly, to measures of financial literacy and financial education does effect thrift. Thrift also appears to have some impact, however small, on the propensity to save. Although the study produced unusual results, the overall conclusion reached is that financial education affects propensity to save without necessarily improving financial literacy. In other words, students who take courses dealing with personal finance may emerge with little improvement in financial literacy, but they may end up more savings oriented than students who have not had a course. Mandell also concludes that even if financial literacy does matter, educators must first determine what areas are most important to teach and the appropriate timetables for educating students (Mandell, 2005).

Bernheim, Garret, and Maki also examined the effects of mandated financial curriculum in schools. Their study utilized the results of a household survey and the variation in curriculum mandates across the states and over time to identify whether mandated curriculum has any impact on the financial behavior of adults. By using regression analysis on variables related to consumer education in high school and adult financial behavior the results have shown that financial education is significantly increased by mandates, and because of this, individuals save at higher rates and accumulate more wealth during their lives. (Bernheim, Maki \& Garrett, 1997, p.30) The results also show that individuals who received personal finance instruction had a savings rate $1.5 \%$ greater than individuals who received no instruction, and wealth is increased by an amount equal to earnings for one year within 15 to 20 years after graduation from high school. These statistics add more evidence to the belief that education can be used to stimulate personal savings (Bernheim, Maki, \& Garrett, 1997).

Hilgert and Hogarth in their article published in the July 2003 Federal Reserve Bulletin, utilized the discipline of behavioral economics as a framework for exploring the differences in consumer knowledge and consumer behavior, and explaining how the two are connected. (Hilgert and Hogarth, 2003, p. 320) Hilgert and Hogarth focus on the four primary activities of financial management, which include credit management, management of cash flow, investment and savings as they analyze data. The data they use comes from monthly Surveys of Consumers and the Survey of Consumer Finances that are conducted by the University of Michigan in order to assess the financial literacy of adults and how it affects their financial behaviors. Eighteen financial-management behaviors were reported on by consumers, like basic skills in managing money, and more sophisticated skills such as diversifying investments. Information about their use of 13 different financial products was also provided. Their results indicated that although a substantially high amount ( 89 percent) of Americans said that they incorporated "good" practices dealing with cash-flow management, less than $50 \%$ of the respondents documented that they 
incorporated plans for spending or budgets. Slightly less than $80 \%$ of respondents were credit card owners, while no more than $33 \%$ of them applied for a credit card before comparing offers. With regard to savings and investing, although savings accounts were present $80 \%$ of the time and emergency funds existed in $63 \%$ of households, 39\% planned on saving mainly for goals on more of a tong-term basis. Only $63 \%$ of the individuals surveyed had a retirement account and only $46 \%$ reported investing in mutual funds. When using an index where behaviors were divided into classifications of low, medium, and high, they found that financial behaviors are hierarchical. This means that individuals with limited amounts of cash should engage in practices that manage their cash flows, but not in saving or investing (Hilgert \& Hogarth, 2003).

Although their research is unclear on the causality of the connection between knowledge of finances and financial behavior, evidence proves that there is a direct correlation. Also, those with high scores on financial literacy exams have a higher tendency to follow beneficial financial practices. Furthermore, their research indicates that individuals with higher levels of knowledge about finances will involve themselves in better financial practices, like prompt payment of bills, budgeting, cash reconciliations and saving (Hilgert \& Hogarth, 2003). They conclude that increased index scores for investment, saving, and credit management practices are partially contributable to understanding and being knowledgeable about investment, savings, and credit respectively. According to this data, improvements in individuals' financial management practices are directly related to the amount of knowledge and experience possessed. (Hilgert \& Hogarth, 2003 p. 321)

A 2001 report issued to congressional requesters by D'Agostino of the General Accounting Office (GAO) in Washington DC, examines the issue of financial inexperience of college students, specifically issues related to college students and credit card debt. Due to the negative media attention surrounding college students and credit card debt, the GAO conducted structured interviews of 100 officials at 12 different universities and colleges around the US and reviewed three different studies of students and credit card use. Additionally, the GAO conducted interviews with officials from consumer groups and representatives of credit card issuers. While examining the advantages and disadvantages of credit card ownership, the GAO concluded that although credit cards can be advantageous to students for many reasons, which include establishing credit histories and for emergency use, many students lack the financial knowledge and experience to use the credit cards responsibly. Researchers were informed by sources such as debt counseling services and University officials that students with no financial experience were more likely incur debts they would be unable to repay (D'Agostino, 2001 p.7) a problem that is exacerbated after graduation when students acquire other expenses such as rent and auto loans and must also begin repaying their student loans. These expenses combined create a substantial repayment burden for students, which because of their financial inexperience may be an issue students are not fully aware of or prepared for prior to graduation. Preparing students for financial independence is considered crucial to their future financial success (D’Agostino, 2001).

Although the issue of college students and their irresponsible credit card usage is itself alarming, the biggest controversy surrounding the issue, the issue garnering the most media attention, relates to the aggressive marketing of credit cards to students. Several universities reported complaints from students related to aggressive solicitation practices. One official described the situation of credit card issuers on campus "a carnival atmosphere" (D'Agostino, 2001 p.8). In response to both controversies, some universities have implemented policies restricting solicitation practices and at least 10 of the universities surveyed are now educating students on financial management, which includes informal presentations, on-line information and debt counseling, which they believe will assist students greatly in their future success and help them to avoid poor financial decisions (D’Agostino, 2001).

Many experts agree mental health, physical health, and even mortality are strongly related to socioeconomic status (Drentea, 2000 p.437) Drentea focuses her study on how negative socioeconomic status (specifically debt) relates to anxiety. Drentea examines measuring financial status by the amount of debt on credit cards, and also, the amount of strain financially and socioeconomic status of individuals with high credit card debt to test whether it is associated with general well-being. The results of her study show that stress resulting from debt was most prevalent in young adults, and that anxiety levels are increased by debt as well. This is mostly related to the larger financial burden experienced by young adults, many of whom are raising families and have not had the opportunity to attain their potential earnings. Drentea concludes that as the ratio of credit card debt to income is increased, the amount of anxiety of the individual with that debt goes up as well. (Drentea, 2000 p.446-447) 
The results of Drentea's study give credence to the movement for mandated financial curriculum in schools. Since it appears that the effects of debt have negative consequences on well-being of consumers, typically those who are young and inexperienced, it is essential that experts and educators assist in reducing the impact of financial hardship on individuals. This can be achieved by implementing early education about financial management and its importance, and the consequences of uneducated decisions.

\section{IMPORTANCE OF PERSONAL FINANCE EDUCATION}

With so much attention focused on personal finance education, many experts have taken to studying the effects of financial literacy on financial management practices. As it stands, most individuals are either self-taught through experience or educated by peers and relatives, as a result young adults are graduating from school completely unprepared for the many critical financial decisions that await them. Studies have shown that individuals will engage in better financial management practices if they have a higher amount of financial knowledge. Many studies have indicated that financial education does impact the financial well-being of an individual. Furthermore, studies show that financial behavior is knowledge specific, meaning that statistically, there are some specific kinds of financial knowledge linked to certain types of financial practices. For example, the more an individual knew about credit, saving, and investment, the more an individual was likely to engage in these same practices (Hilgert \& Hogarth, 2003). Studies on household credit management and mortgage practices have proven the fact that delinquent mortgage payments were a lot less common in those households who underwent credit counseling as well as those households instituting better credit management practices and having better credit scores (Hilgert \& Hogarth, 2003). Additionally, there are several criteria that contribute to better financial management in households, including childhood education, attitudes toward spending, social norms, and public policies that maintain incentives for individuals who practices habits of good financial management, like saving for retirement (Hilgerth \& Hogarth, 2003 p. 312).

Financial management practices are not limited to their effect on a household's financial status; studies have also proven that financial management practices can also affect an individual's mental and physical health. In other words, poor financial management can lead to more anxiety and stress in life. This is especially true for younger families, which experience more financial hardship in their early years when earning potential has not been reached by those in early stages of adulthood and younger families are establishing households and families. Consequently, these same families may find themselves dealing with substantial amounts of credit card debt. Eventually, high outstanding debt on credit cards might lead to the purchase of essentials of poor quality. Many times credit card debt, unlike debt related to homes or cars, is seen as excessive and that those with credit card debt lack self-control and discipline when in fact, many people accumulate credit card debt during periods of unemployment or when faced with medical problems. Regardless of the circumstances surrounding the acquisition of credit card debt, it is evident that the more debt one acquires the more anxiety and health problems one is likely to have. (Drentea, 2000 p.439)

\section{THE US ECONOMY: IMPETUS FOR CHANGE}

The American economy has undergone dramatic changes in recent years. Americans experienced a dramatic stock market decline followed by an increase in unemployment. As the economy recovered many Americans found themselves dealing with a jobless recovery as multi-national companies moved their operations abroad to take advantage of lower costs of labor. Healthcare costs have risen by unprecedented proportions leaving millions of Americans uninsured. Social security is at the forefront of political debates and is only a couple of decades away from insolvency, while at the same time households are saving less and less for retirement. Bankruptcy claims in the US have surged to record levels. In 2003, more than 1.6 million consumers filed for bankruptcy, an unprecedented number. Overstretching of budgets and over borrowing are pushing many American families into bankruptcy; close to one-third of individuals that file bankruptcy owe at least one year's income in credit card debt (Warran \& Tyagi, 2003). Based on current trends in the economy - inadequate savings, dramatic increases in home prices and consumer goods, rising bankruptcy claims and credit delinquency - many households appear unable to manage finances and set good examples for their children. With so much financial uncertainty surrounding many American households, it is imperative that educators take bigger steps towards educating children, young adults, and adults on the perils of poor financial management and the importance of financial literacy. 


\section{Debt In America}

Debt has become a part of life for many American households as more and more families struggle to meet growing financial obligations. As it becomes easier to access credit, American families are swimming in a sea of debt. Currently, it is estimated that the typical household in America carries $\$ 10,000$ to $\$ 12,000$ estimated total revolving debt. Debt on credit cards is not limited to families though, the aggressiveness of credit card companies towards targeting students has left many students saddled with debt before they even graduate from college; $45 \%$ of college students now hold approximately $\$ 3,000$ in credit card debt (www.jumpstart.com).

Undoubtedly, credit cards can be highly useful and convenient financial instruments, students can use them to pay for books or to establish credit, or paying for unexpected expenses. Credit cards can also provide families and students with some security, such as when a card is stolen, cardholders are not liable for fraudulent purchases, unlike stolen cash which is often irreplaceable. Credit cards when used wisely can also be a tool for learning financial responsibility. However, when credit cards are given to persons who lack the responsibility and financial experience to use them wisely, the credit card debt may become costly and difficult to repay. This is especially true for students who have not been fully educated in financial management. Many students will leave college burdened with large student loan balances in addition to credit card debt. Students may exploit the convenience of credit cards by making unwise purchases. Students may be unaware of the effect of incurring excessive debt, the cumulative effect of interest rates, and making late payments and generally living beyond their means. In an economy where employment for recent college graduates is uncertain, many students may find themselves dealing with financial insolvency before they have found their first full-time job (D'Agostino, 2001).

Revolving debt is not the only cause for concern, housing prices have risen dramatically in recent years and many American families are struggling to attain what was once considered a rite of passage-their first home. Although record-low interest rates and exotic loans, such as interest-only mortgages, have helped many first time home buyers, housing prices continue to increase dramatically forcing many families out of markets. Experts are concerned that households are stretching their budgets too thin and are taking on riskier loans that may result in losses if and when the current real-estate bubble bursts (McGinn, 2003).

\section{The Outlook For Savings And Investing}

One of the most heated political and social issues today is the status of the social security system. With a projected insolvency by the year 2041, many Americans are now waking up to the reality that retirement may be unattainable. Although the social security system is only supposed to supplemental one's own personal retirement account, that supplement may no longer be an option for many. It is anticipated that as early as 2017, social security will pay more in benefits than it will receive in taxes. In order to fully fund the program, the government would have to raise payroll taxes to an astronomical $30 \%$ (Bloom \& Schirm, 2005).

With such dismal figures related to social security it would appear that American families would be saving and investing more and spending less. However, studies have shown that less than half of US households do not have funds in savings specifically set aside for emergencies and to provide some monetary cushioning to protect against negative side effects of economic shock such as, job loss, health issues, or repairs on cars and appliances (Hilgert \& Hogarth, 2003).

Much of the behaviors related to saving investing can be explained when one considers the current state of the US economy. However, the myriad and complexity of investment tools combined with the lack of financial knowledge of individuals, have led many consumers to make poor financial decisions. Many individuals lack the resources to seek out financial advice from experts and lack the knowledge base to explore investment opportunities on their own. Without solid financial knowledge and skills, one cannot possibly budget for household finances appropriately, save for college, or plan for retirement.

Although most children are introduced to the concept of savings early on, statistics show that savings patterns of young people are deficient. In 2003, America's young people ages 8 to 21 earned about $\$ 211$ billion in 2003. Of 
those earnings, approximately $\$ 172$ billion is being spent while only $\$ 39$ billion is being saved (www.jumpstart.com). Financial experts believe that at least $10 \%$ of income should be saved per month and that households should have emergencies funds equal to living expenses for $16.67 \%$ to $50 \%$ for one year. However, numerous studies have shown that a large percentage of households do not save regularly and do not have adequate emergency funds. The saving practices of households, children, and young adults is indicative of a negative pattern of financial management that begins early on and continues through adulthood.

\section{PERSONAL FINANCE EDUCATION TODAY}

\section{A Family Matter}

Traditionally, personal finance education was thought to be a family matter. Many believed it is a parent's responsibility to educate their children on financial matters. While no on can argue that it is always the parent's responsibility to educate their children on a number of matters, it is also the responsibility of society, specifically educators, to supplement their education with standard and adequate curriculum. A 2004 survey of adults and parents conducted by Visa found that according to parents, high school students with no budget total $78 \%$ and that $56 \%$ of high school graduates are unprepared to handle their own personal finances. Only $62 \%$ of parents require their high school students to have some savings and $37 \%$ of parents will have an itemized back to school budget, while $61 \%$ will not (www.jumpstart.com). Additionally, a 2003 survey conducted by FleetBoston found that less than half of the adults surveyed felt that with regard to savings and spending, they were good role models for their children. Only $26 \%$ of those surveyed felt that they themselves were well prepared to teach their own children about the basics of personal finance (www.jumpstart.com).

With what appear to be such disappointing statistics, it is evident that parents alone cannot be relied upon to convey to their children responsible financial behavior. More concerning are the statistics that reveal the dependence of children on their parents for financial guidance. A 2003 survey conducted by Capitol One found that $87 \%$ of college students and $90 \%$ of high school students depend on their parents for financial guidance, while $70 \%$ of college students say their parents have not given them advice about spending responsibly with regard to schools supplies (www.jumpstart.com).

\section{Survey Of States}

The fourth biennial survey on the state of economic and personal finance education titled "Economic and Personal Finance Education in our Nation's Schools in 2004" was conducted by the National Council on Economic Education (NCEE). The NCEE is a national non-profit organization that is tasked with promoting economic literacy to students and their teachers. Overall the results of the survey showed little improvement in economic education requirements, but more improvement in advancing personal finance education. In 2004, forty-nine states included economics in school standards, thirty-eight states reported personal finance standards, twenty-one states require that standards must be implemented, 7 states make a course in personal finance education a graduation requirement and 9 states require testing in personal finance. Although the 2004 survey shows improvement from 2002, progress is slow and many states have not adopted personal finance education into core curriculum and are not as adamant about making it necessary for teacher certifications or even for graduating. Although improvements have been made, generally the current standards and statistics are well below what is needed for the majority of American students to be financially literate (NCEE, 2005).

\section{SOLUTIONS FOR CHANGE}

Because educators, businesses, community groups, government agencies, and policy makers are becoming increasingly concerned with consumer literacy community groups, businesses, government agencies, and policy makers, it appears that the present is the time to emphasize personal financial education in our schools systems. However, financial education should not stop once an individual has reached the end of their academic career. Many organizations recognize the need for financial education in adults. Considering that the financial knowledge of peers 
can affect the knowledge of related individuals, it would be advantageous to provide ample resources for all individuals.

While it is necessary to educate students and adults about financial management, it is important to recognize and provide education at a "teachable moment". Individuals such as, first-time homebuyers, are more likely to retain and utilize information more appropriately when provided at this critical moment. However, increasing awareness of "teachable moments" is one challenging aspect of providing financial education to individuals of motivating them to pursue it (Hilgert \& Hogarth, 2003 p. 320). Furthermore, experts agree that a distinction exists between being provided with education and being provided with information and all concerned parties must recognize this distinction. According to Hilgert and Hogarth, in order to make changes in behavior, there must be a combination of education, building skills, and motivation. Providing easily accessible information to students is essential to increasing awareness, however, providing education can have substantial results in increasing financial literacy and motivating change (Hilgert \& Hogarth, 2003). Although educating high school students is undeniably important, many question whether students are being educated early enough in their academic careers. It would be more beneficial to begin a student's financial education in their elementary years, at a time when students are more susceptible to the teachings of finance and to continue their personal finance education throughout their academic career, building on the foundation set during their elementary years.

Additionally, mandating personal financial education for students at the college level is also essential as it would allow students to manage their finances at a time when they are at the threshold of financial freedom and are just beginning to navigate the complex maze of financial instruments available to them. During this critical period, a more in depth study of financial markets and their instruments would be more appropriate.

Recommendations include:

1. Integrate and mandate economics and personal finance into the core curriculum in K-12.

2. Provide well-trained teachers through high-quality teacher training and certification to teach economics and personal finance in schools.

3. Monitor progress to ensure that all individuals involved in the education process have the tool necessary to promote economic and personal finance.

4. Teach cash flow management, which includes, responsible bill paying, budgeting, reconciliations, and basic financial analysis of spending patterns. Learning how to manage cash, budget properly and set aside ample savings will help many individuals avoid financial ruin at critical times, such as during periods of unemployment, and will help define a pattern of good financial behavior that can be passed down through generations.

5. Teach credit management, which deals with effectively managing the family debt to income ratio. Easy access to lines of credit has left many consumers saddled with enormous amounts of debt. Additionally, the solicitation practices of credit issuers are most effective on younger adults, specifically college students who lack the financial resources to support themselves through school. While many students receive financial aid, the lure of credit card companies may be too strong for even the most financially savvy students when it comes time to pay for even the smallest essentials. It appears one way to help students avoid acquiring too much debt is to educate them on disadvantages of credit card debt and its implications for their futures. This would include and examination of the effect of high credit card balances on credit ratings, which will directly affect future financial resources and purchasing decisions. Rather than focusing solely on the disadvantages of credit cards, an educator should focus on the advantages as well; this would include teaching students to use credit cards wisely and teaching responsible repayment of debt and how credit cards can positively affect credit ratings 
6. Teach saving and investing, which would include establishing emergency funds and subsequently having investment goals, short-term as well as long-term, such as purchasing a home and saving for retirement. Investing can prove to be one of the more difficult aspects of personal finance education. Investors must typically deal with a myriad of investment tools and lack the time or knowledge to effectively analyze the markets and choose investment options accordingly. However, even at the most basic level, the benefits of investing in more common and less risky investments certainly outweigh the alternative of not investing at all.

7. Provide funding to support state and local efforts to promote personal finance education and provide funding that specifically for disseminating valuable information to consumers on a constant basis.

8. Implement reforms to restrict solicitation practices of credit card issuers and implement policies which include providing examples of repayment schedules to be included in monthly statements that will assist cardholders with analyzing their financial situations.

By providing individuals, especially young students, with the skills necessary to manage their personal finances, they will successfully develop into productive and successful members of society by becoming better at saving and investing and by becoming more knowledgeable consumers. Furthermore, they will become productive members of our global economy and contribute to the general well-being of society.

\section{CONCLUSION}

It is very clear that the spending and saving patterns in American households and overall financial management behavior are directly affected by trends in the US economy. Unfortunately, many American homes suffer from lack of financial education and awareness, and this causes them to make poor decisions about managing their finances. These poor decisions and lack of knowledge lead children in these households to being unexposed to correct financial behaviors and then those children grow up making poor financial decisions. Studies also show that anxiety and stress are directly related to amount of financial education, and those lacking that education have higher levels of stress and diminished health. Therefore, it is only logical that community groups, high schools and colleges should be more involved in educating America's youth and helping inform those who lack financial knowledge. The study suggests several ways to achieve these goals, the most important being that our decisions makers (either U.S. Congress or a University President), are willing to devote a large percent of their efforts to educating the American public so that the country can become more financially sound at the household level. 


\section{REFERENCES}

1. Bernheim, B.D., Maki, D.M. and Garrett, D.M. (1997) Education and Saving: The Long-Term Effects of High School Financial Curriculum Mandates. NBER working paper w6085, National Bureau of Economic Research, July 1997.

2. Bloom, R. and Schirm, D. (2005). Social Security: The Topic du Jour, Part 1, Strategic Finance, July 2005.

3. D. Agostino, D.M. (2001) Consumer Finance: College Students and Credit Cards. Report to Congressional Requesters. Washington D.C. General Accounting Office, Report No. GAO-01-773 (78 pages).

4. Drentea, P. (2000) Age, Debt and Anxiety. Journal of Health and Social Behavior. December 2000, Vol. 41, No. 4, p 437-450.

5. Hilgert M. and Hogarth, J. (2003) Household Financial Management: The Connection Between Knowledge and Behavior. Federal Reserve Bulletin, July 2003.

6. Making the Case for Financial Literacy - 2005. Retrieved from http://www.jumpstart.org/download.cfm.

7. McGinn, D. (2003) Housebound,. Newsweek. September 15, 2003, Vol. 142 Issue 11, p60, 3p, 3 graphs, 1c.

8. National Council on Economic Education (NCEE). (2005) Survey of the States: Economic and Person Finance Education in Our Nation's Schools in 2004. March 2005.

9. Mandell, L. (2005) Financial Literacy - Does it Matter?, Washington D.C.: The Jumpstart Coalition for Personal Financial Literacy (13 pages). Retrieved from: http://www.jumpstart.org/ download.cfm.

10. Warren, E. and Tyagi, A. (2003) The Two-Income Parent Trap, Why Middle-Class Mothers and Fathers Are Going Broke. New York: Basic Books, 2003. 


\section{NOTES}

